\title{
Protestantismo e educação no Brasil e na América Latina
}

\author{
José Normando Gonçalves Meira ${ }^{1}$ \\ Shirley Patrícia Nogueira de Castro e Almeida ${ }^{2}$ \\ Wendell Lessa Vilela Xavier ${ }^{3}$
}

O dossiê buscou reunir artigos que discutem as ações educacionais protestantes no Brasil e na América Latina, considerando a relação dessa vertente do cristianismo com a educação escolar desde a Reforma Protestante do Século XVI. O impacto das convicções religiosas protestantes nos diversos aspectos da cultura moderna tem sido destacado por autores das diversas áreas do conhecimento, tendo como referências teóricas abordagens mais amplas tais como a de Weber (2004) e Biéler (2012) e outros. No que diz respeito especificamente à educação escolar, a influência do protestantismo, tem sido reconhecida e discutida por diversos autores dessa área do conhecimento e de outras que com ela dialogam. Cambi (1999) Nunes (2017); Vieira (2008), Burke (1995), Chartier (1989), servem como exemplo. Alguns aspectos das convicções religiosas protestantes e da sua teologia justificam essa relação com a educação escolar: a doutrina do "sola Scriptura", de que a Bíblia é a fonte do conhecimento do ser de Deus e da sua vontade para a vida do homem. Entendem que "às Escrituras do velho e do Novo Testamento" devem estar sujeitos todas as decisões dos concílios e as elaborações teológicas dos doutores da Igreja. A leitura e interpretação do texto sagrado constitui-se em fundamento para a verdadeira religião. Embora o entendimento espiritual desse conteúdo dependa de uma comunicação especial de Deus, requer também esforço intelectual e um estudo correto desse texto. Enquanto para a Igreja medieval, o estudo da Bíblia era uma função específica do clero, que mediava o relacionamento do indivíduo com Deus, a Reforma Protestante do Século XVI afirmava não ter base bíblica essa

\footnotetext{
${ }^{1}$ Doutor em Educação. Professor do Programa de Pós-Graduação em Educação da Universidade Estadual de Montes Claros (Unimontes). Minas Gerais, Brasil. E-mail: jose.meira@unimontes.br ORCID: https://orcid.org/0000-0003-1105-4322.

${ }^{2}$ Doutora em Educação. Professora do Programa de Pós-Graduação em Educação da Universidade Estadual de Montes Claros (PPGE/Unimontes), Minas Gerais, Brasil. E-mail: shirley.almeida@unimontes.br ORCID: https://orcid.org/0000-0002-4785-7963.

${ }^{3}$ Doutor em Letras. Professor do Instituto Federal do Norte de Minas Gerais - IFNMG. Minas Gerais, Brasil. E-mail: wendell.xavier@ifnmg.edu.br. ORCID: https://orcid.org/0000-0002-7955-2785.
} 
mediação. Firmou a doutrina do "sacerdócio universal dos cristãos". Essa convicção implicaria na necessidade de todos os cristãos, individualmente, conhecerem o conteúdo bíblico. A alfabetização era para eles uma necessidade por razões de fé. Além da alfabetização para os objetivos imediatos da proclamação do Evangelho e o discipulado dos conversos, o protestantismo incentivava a educação escolar, a produção do conhecimento como uma forma de "glorificar a Deus". É o que Weber (2004) chama de “ascetismo intramundano". Para ele, o protestantismo nega o mundo, enfrentando-o com o objetivo de transformá-lo. Neste caso, o conhecimento da realidade, da natureza, é uma das formas para que o homem cumpra o mandato cultural que lhe fora dado no ato da criação: "Tomou, pois, o Senhor Deus ao homem e o colocou no jardim do Éden para o cultivar e o guardar" (Gênesis 2:15). Para exercer um domínio responsável sobre o mundo, é necessário conhecê-lo. Além disso, criado "à imagem e semelhança" do seu Criador, o homem tem um potencial a ser desenvolvido e a educação escolar é um instrumento considerado importante para isso. Esta é a razão pela qual o protestantismo, na proposta de "voltar às Escritura", além das escolas elementares, de alfabetização, procurou criar colégios e universidades que pudessem ampliar a busca de conhecimentos nas diversas áreas.

A historiografia da educação brasileira tem se ocupado dessa temática, procurando compreender as ações dos protestantes que aqui chegaram de forma definitiva em meados do século XIX, tendo nos empreendimentos educacionais, importante estratégia para o estabelecimento das suas igrejas e como parte fundamental da própria mensagem que se consideravam portadores.

Neste dossiê, foram reunidos estudos que tratam do referido protestantismo missionário que estabeleceu relações permanentes no Brasil a partir de $1855 \mathrm{com}$ a chegada dos Congregacionais e de 1859 quando os presbiterianos também aqui se estabeleceram. Projetos educacionais que foram executados ainda no período imperial, na fase de implantação dessa vertente religiosa no país, e também após à proclamação da República, período considerado da sua consolidação. Reúne estudos que discutem também outras fases do protestantismo na América Latina, especificamente durante as tentativas de estabelecimentos dos franceses e holandeses na América Portuguesa. As experiências francesas na Baía da Guanabara, no século XVI e no Maranhão, no século XVII, além da estada dos holandeses, considerada marcante na região que atualmente é o nordeste brasileiro. Há também estudos que tratam do chamado "protestantismo de 
imigração", que utilizou-se da relativa tolerância religiosa no Brasil a partir de 1810 e que foi mantida na Constituição de 1824.

Os artigos que compõem o dossiê, apontam para o potencial da temática, considerando a diversidade de aspectos e temas a serem explorados. O professor Wilson Santana, com o artigo "Fundamentos Históricos do Protestantismo Brasileiro: Uma introdução", abrangendo as fases supra mencionadas, possibilita ao leitor uma visão panorâmica da história do protestantismo brasileiro. Christian Brially, com o artigo " As Representações Imagéticas do Relato de Viagem de Jean De Léry: Uma contribuição calvinista à temática indígena", discute as implicações das convicções teológicas calvinistas referentes à natureza humana no seu relacionamento com os indígenas, especialmente o povo Tupinambá. O texto propõe reflexões referentes a uma determinada visão de mundo e as implicações no que concerne à humanidade indígena. A pesquisadora Ester Fraga Vilas-Bôas Carvalho do Nascimento, com o artigo "Brasil, Inglaterra e Portugal: circulação de impressos protestantes no Nordeste brasileiro", aborda as práticas de leitura protestantes antes mesmo do estabelecimento das missões e como a circulação de literatura serviu como estratégia para a ação missionária e, como parte dessa missão, a criação de escolas para alfabetizar os leitores em potencial da literatura distribuída. A pesquisa contribui para ampliar os estudos referentes à relação entre a fé protestante e a educação escolar, especialmente em um país como o Brasil do século XIX onde o acesso à educação escolar era bastante limitado. Embora o trabalho tenha o seu foco na região nordeste, aponta ações em outras regiões do país, servindo, inclusive de estímulo a outras investigações. Marcel Mendes e Lucas Resende apresentam "Protestantismo e Educação Social: uma análise histórica de iniciativas promovidas pela mais antiga instituição educacional presbiteriana do Brasil", estudo no campo da história das instituições escolares, problematizando as origens de um educandário que, iniciado em Campinas-SP, no final do século XIX, deslocou-se para Lavras no oeste de Minas Gerais, tornando-se uma referência regional pelas diversas iniciativas que se inseriram nos ideais de modernização, desenvolvimento e progresso pertinentes às primeiras décadas da República brasileira. Por fim, o artigo “ A Influência Protestante na Obra de Othoniel Motta e sua Influência para a Educação Brasileira", analisa os pressupostos teóricos desse educador, identificando nos seus escritos, elementos de uma cosmovisão protestante e qual o impacto social de tais convicções. 
Espera-se que essa iniciativa cumpra o seu objetivo de ampliar as discussões referentes às práticas educativas protestantes no Brasil e na América Latina, oriundas das missões norte americanas e outras vertentes em diferentes períodos. Que as pesquisas aqui reunidas com as questões por elas enfrentadas e por aquelas que elas poderão deixar em aberto, que outros estudos sejam realizados nesse fértil campo de estudo.

\section{REFERÊNCIAS}

BIÉLER, André. O Pensamento Econômico e Social de Calvino. 2. Ed. São Paulo: Cultura Cristã, 2012

BURKE, Peter; BOTTMANN, Denise. Cultura popular na idade moderna: Europa, 1500-1800. São Paulo: Companhia das Letras, 1995.

CAMBI, Franco. História da Pedagogia. São Paulo: UNESP, 1999

CHARTIER, Roger. As práticas da escrita. In. CHARTIER, Roger (Org.) História da vida privada, v. 3. Companhia das Letras, 1989.

NUNES, César. Ide, Ensinai a Todos: Os 500 anos da pedagogia luterana. Porto AlegreRS, 2017.

VIEIRA, Paulo Henrique. Calvino e a Educação: A Configuração da Pedagogia Reformada do Século XVI. São Paulo: Mackenzie, 2008

WEBER, Max. A Ética Protestante e o Espírito do Capitalismo. São Paulo: Companhia das Letras, 2004. 